\title{
Щодо формування системи показників оцінювання збитків національної економіки у період збройного конфлікту (війни)
}

\author{
Костянтин Харитонов * А \\ А Командування військ зв'язку та кібербезпеки Збройних Сил України, пр-кт Повітрофлотський 6, м. Київ, 03168, Україна
}

Received: December 05, 2020 | Revised: December 16, 2020 | Accepted: December 31, 2020

JEL Classification: H56.

DOI: $10.33445 / s d s .2020 .10 .6 .11$

\begin{abstract}
Анотація
У статті описана система показників для оцінки економічних збитків держави, що виникають в результаті збройного конфлікту. Аналіз літератури показує, що сьогодні використовуються різні методи оцінки збитків національної економіки під час збройного конфлікту, кожен із яких має свою спеціальну систему показників. Система показників, що дасть можливість встановити зв'язок між державними втратами під час збройного конфлікту та економічним зростанням держави, не зустрічається. Метою роботи $\epsilon$ пошук системи показників, яка дозволить вирішити це проблемне питання.

У статті представлені основні складові економічних втрат, а точніше: прямі військові витрати країни, втрачені доходи, що залежить від кількості постраждалого населення, додаткові державні витрати уряду, а також непрямі втрати держави, які виникають 3 початком збройного конфлікту: переміщення населення, еміграція кваліфікованих робітників та втрата можливостей освіти для майбутніх поколінь. Врахування всіх складових економічних збитків, що виникають внаслідок збройного конфлікту, впливає не тільки на загальну суму збитків, але і на рівень економічного розвитку держави. Застосування показників у запропонованій системі, з одного боку, встановлює зв'язок між економічним розвитком держави та компонентами економічних збитків, спричинених збройним конфліктом, а, з іншого боку, дає змогу здійснити оцінку цих втрат.

Для прийняття більш обґрунтованого рішення щодо економічного розвитку нашої держави слід використовувати запропоновану систему показників оцінки збитків для національної економіки в період збройного конфлікту. У майбутньому застосування такої системи дозволить встановити зв'язок між обсягом збитків та економічним зростанням держави.
\end{abstract}

Ключові слова: збройний конфлікт, економічні збитки, валовий внутрішній продукт, втрата продуктивності праці, втрачений заробіток.

\section{Постановка проблеми}

Будь-який збройний конфлікт впливає на економічне зростання країни, оскільки внаслідок ведення бойових дій знищуються їі ресурси, руйнується інфраструктура, а також спостерігається відтік людських ресурсів. Тобто держава зазнає збитків, які виникли через втрати, що мають місце під час збройних конфліктів, а ці збитки відображаються на економічному зростанні країни. Крім того, швидкість відновлення національної економіки після збройного конфлікту теж безпосередньо буде залежати від завданих збитків.

Анексія Криму та воєнні дії на сході України в окремих регіонах Донецької та Луганської областях негативно впливають на економічні показники розвитку всієї країни. Різке скорочення обсягів валового внутрішнього

\footnotetext{
* Corresponding author: здобувач, e-mail: aosemenenko@ukr.net
} 
продукту (далі - ВВП) України, пов'язане в основному із закриттям, переміщенням або призупиненням діяльності підприємств, інфраструктурними втратами, зменшенням кількості робочих місць, значним падінням доходів населення та вимушеною міграцією. Для виміру економічних збитків України, які настали внаслідок збройного конфлікту на сході країни, необхідно мати певну систему показників, яка надасть можливість здійснити вартісне оцінювання зазначених збитків та встановити взаємозв'язок між зазначеними збитками та економічним зростанням держави.

Отже, можна визначити проблемне питання, а саме: відсутність системи показників для проведення вартісного оцінювання економічних збитків держави, які настали внаслідок збройного конфлікту.

\section{Аналіз останніх досліджень та публікацій}

Аналіз літератури щодо оцінювання економічних збитків країн, де мали місце збройні конфлікти, свідчить, що нині застосовують різні методи для проведення оцінювання збитків національної економіки у період збройного конфлікту, кожен з яких має свою особливу систему показників. Більшість досліджень визначають економічні наслідки війни як втрачену частку ВВП та в основному зосереджені на зменшенні національного доходу [1], [2], [3]. У багатьох випадках економічна оцінка враховує ефекти, які можуть бути безпосередньо пов'язані 3 конфліктом, але не містить непрямі ефекти, які збільшують тягар конфлікту. Один 3 підходів - визначення вартості відновлення знищених ресурсів. Цей метод містить систему показників із прямих та непрямих втрат під час конфлікту, але його недоліком $\epsilon$ те, що ці втрати оцінюються із застосуванням емпіричних підходів [4]. Інший метод відомий як контр-фактичний аналіз ВВП. Він полягає в моделюванні зміни ВВП, яке базується на оцінці економічного зростання і загального благополуччя країни за відсутності конфлікту [5]. Для України проведене оцінювання вартості підприємств 3 урахуванням фактору війни [6] та досліджено економічні втрати i руйнування інфраструктури країни в роки Другої світової війни [7]. Крім того, проведене вартісне оцінювання економічних збитків окремих регіонів України за частковими показниками, які мають місце внаслідок конфлікту на сході нашої країни [8] та представлена оцінка збитків України, у період збройного конфлікту на Донбасі [9]. Узагальнена ж система показників, яка надасть можливість здійснити вартісну оцінку економічних збитків внаслідок збройного конфлікту на сході України, в науковій літературі не зустрічається.

\section{Постановка завдання}

Тому мета статті - вирішити проблемне питання щодо відсутності системи показників для оцінювання збитків національної економіки у період збройного конфлікту та сформулювати таку систему показників.

\section{Виклад основного матеріалу}

Вартісна оцінка економічних збитків України, які виникли внаслідок конфлікту на сході країни, залежить від факторів, які впливають на обсяг ВВП. Безпосередньо впливають такі фактори:

по-перше, військові витрати. В основному це витрати, які передбачені бюджетом Міністерства оборони України, а також бюджетами інших силових структур та відомств;

по-друге, втрачені доходи країни, які мали місце внаслідок збройного конфлікту. Вони містять: втрату продуктивності праці внаслідок міграції населення та втрачений заробіток через загибель людей під час конфлікту; 
по-третє, додаткові державні витрати, які настали внаслідок збройного конфлікту.

Непрямий, опосередкований вплив здійснюють такі фактори, як: відтік капіталу, еміграція кваліфікованої робочої сили та втрачені освітні можливості для майбутніх поколінь.

Вартісне оцінювання необхідно проводити за певний період $t$, цей період оцінювання може охоплювати як весь період збройного конфлікту, так і його частину.

Слід зазначити, що врахування всіх складових економічних збитків, які виникають внаслідок збройного конфлікту, мають вплив не лише на загальний обсяг збитків держави, а й на рівень економічного розвитку держави. При цьому рівень економічного розвитку держави може визначатися як ВВП країни у цілому, так й ВВП на душу населення. Система показників, яка надасть можливість, 3 одного боку встановити взаємозв'язок між економічним розвитком держави та складовими економічних збитків, що настали внаслідок збройного конфлікту, а з іншого - здійснити вартісне оцінювання зазначених збитків, можна представити у вигляді схеми, зображеної на мал.

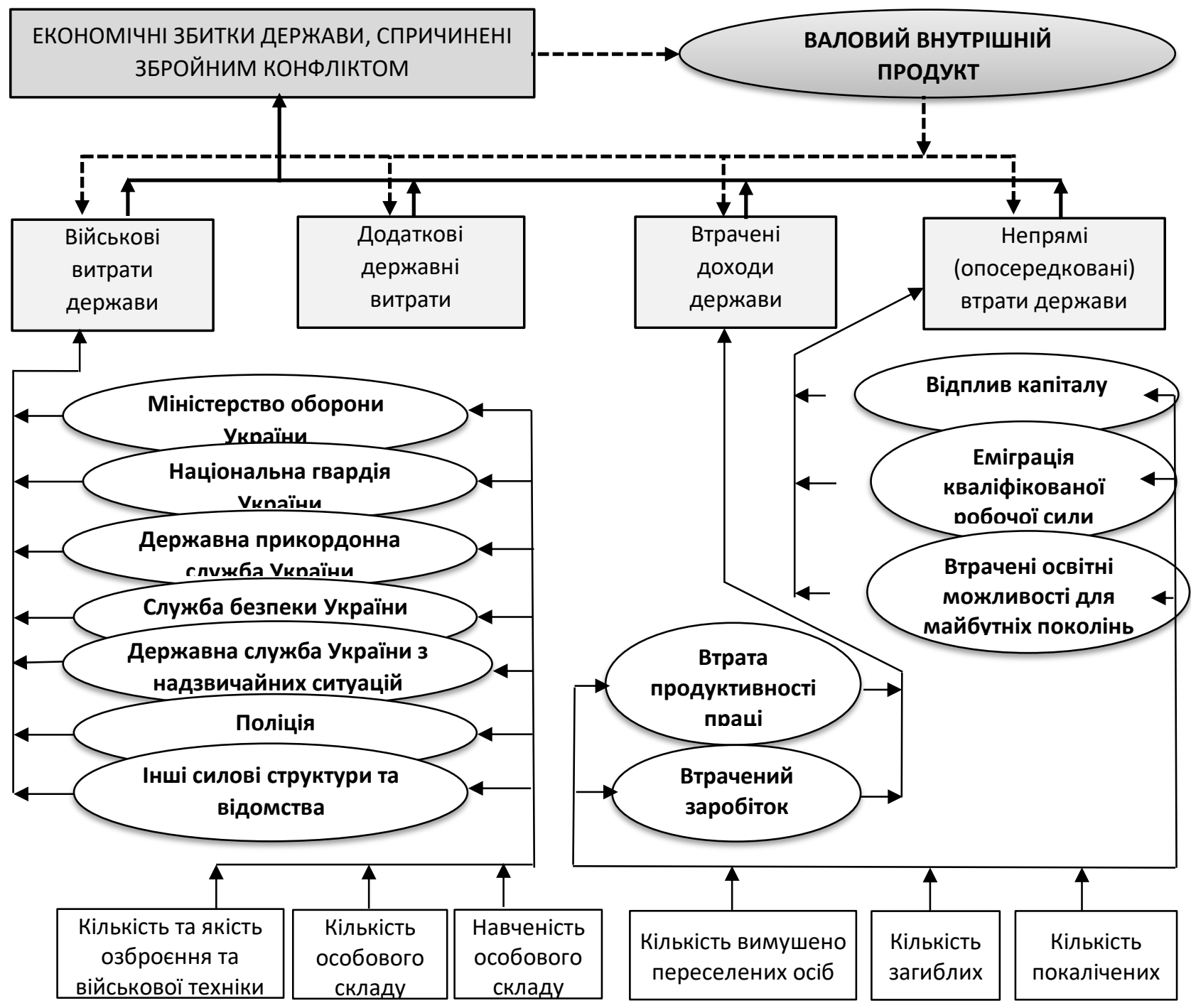

Малюнок - Система показників для здійснення вартісного оцінювання економічних збитків країни внаслідок збройного конфлікту

Як засвідчує аналіз зарубіжного та час збройного конфлікту збільшуються та вітчизняного досвіду, військові витрати під стають додатковим тягарем для економіки 
країни, де має місце збройний конфлікт. Обсяг цих витрат в основному залежить від якості та кількості наявного озброєння та військової техніки в силових структурах країни, навченості, підготовленості та укомплектованості особового складу в них.

Населення, що перебуває у зоні конфлікту, швидше за інших бідніє, діти втрачають можливість відвідувати школу, люди не мають доступу до медичної допомоги. Ці проблеми мають довгостроковий вплив на обсяг доходів у країні і, відповідно, на економічний іï розвиток. Раніше проведені дослідження встановили, що втрата продуктивності внаслідок переміщення та загибелі людей $\epsilon$ головною причиною пригнічення економічного зростання країни, де має місце збройний конфлікт [4]-[7]. Отже, для кількісного оцінювання економічних збитків України внаслідок збройного конфлікту на сході країни необхідно спочатку визначити кількість постраждалого населення, а саме вимушено переселених осіб (внутрішньо переміщених осіб та біженців), а також загальне число загиблих унаслідок конфлікту. При цьому потрібно розуміти, що біженці - люди, які покинули власну країну та виїхали за їі межі, внутрішньо переміщені особи - люди, які були змушені покинути власні домівки в межах своєї країни. Далі можна зробити вартісне оцінювання втрат доходів країни, вони будуть залежати від втрати продуктивності праці постраждалого населення та втраченого заробітку загиблих унаслідок конфлікту.

Вартісну оцінку втрачених доходів України необхідно визначати з урахуванням обсягу ВВП на одну особу у відповідний період та кількості економічно активного працездатного населення. При цьому втрата продуктивності праці постраждалого населення, яка виникла внаслідок збройного конфлікту за період $t$, буде залежати від кількості внутрішньо переміщених осіб унаслідок конфлікту за період $t$ та кількості біженців унаслідок конфлікту за період $t$.

Втрачений заробіток загиблих унаслідок конфлікту на сході України залежить від кількості жертв (загиблого населення)
України, а також їх віку. Більшість постраждалого населення могло 6 працювати та приносити дохід державі ще не одне десятиріччя. Тому під час визначення втраченого заробітку загиблих унаслідок конфлікту на сході України буде враховуватися заробіток за весь час можливого життя загиблих, а індикатором доходу на одну особу буде виступати показник середньої заробітної плати за період $t$. Крім того, під час оцінювання слід використовувати діапазон заробітку від п'яти до двадцяти п'яти років, оскільки ймовірний заробіток за життя за умови відсутності конфлікту формується, враховуючи різну тривалість життя. Зокрема, середня тривалість життя в Україні дає підстави стверджувати, що можливий заробіток може дорівнювати заробітку за п'ятнадцять двадцять років. Таким чином, втрачений заробіток загиблих унаслідок збройного конфлікту за період $t$ буде перебувати в діапазоні від мінімально втраченого можливого заробітку за період оцінювання $t$ до максимально втраченого можливого заробітку за період оцінювання $t$.

Ще одним показником, який відображає обсяг економічних збитків України внаслідок збройного конфлікту на сході країни, $€$ додаткові державні витрати, які виникають в зазначений період часу. До таких витрат слід віднести допомогу, надану урядом внутрішньо переміщеним особам. Зокрема, в Україні 3 метою соціальної підтримки внутрішньо переміщених сімей (осіб) у 2014 році уряд прийняв постанову № 505 “Про надання щомісячної адресної допомоги внутрішньо переміщеним особам для покриття витрат на проживання, в тому числі на оплату житлово-комунальних послуг" [10]. Крім того, в державному бюджеті передбачаються кошти для реалізації програм соціального захисту учасників антитерористичної операції та операції Об'єднаних сил та членів їх сімей [11]-[13]. Зокрема, здійснення заходів із психологічної та медичної реабілітації, професійної адаптації, забезпечення санаторнокурортним лікуванням тощо. Отже, витрати, 
передбачені на реалізацію зазначених заходів теж слід враховувати під час визначення додаткових державних витрат.

ще однією складовою додаткових державних витрат є гуманітарна допомога, надана державою особам, які проживають в зоні конфлікту. Таким чином, додаткові державні витрати будуть визначатися усіма додатково витраченими державою коштами на допомогу.

Треба зазначити, що на обсяг економічних збитків країни під час збройного конфлікту впливають непрямі (опосередковані) втрати, а саме: витіснений капітал, еміграція кваліфікованих робочих та втрачені освітні можливості для майбутніх поколінь. Врахування зазначених втрат буде лише збільшувати вартість економічних збитків країни внаслідок збройного конфлікту та негативно позначиться на рівні економічного розвитку держави.

\section{Висновки}

Таким чином, у статті представлена система показників для оцінювання збитків національної економіки у період збройного конфлікту. Зазначена системи містить складові економічних втрат, а саме: прямі військові витрати країни, втрачені доходи, що залежать від кількості постраждалого населення, додаткові державні витрати уряду, а також непрямі втрати держави, які виникають з початком збройного конфлікту: переміщення населення, еміграція кваліфікованих робітників та втрата можливостей освіти для майбутніх поколінь. Застосування сформульованої системи показників для вартісної оцінки економічних збитків країни внаслідок збройного конфлікту надасть можливість визначити втрати держави під час збройного конфлікту та у подальшому встановити їх взаємозв'язок із рівнем економічного розвитку держави. Все це буде сприяти більш обгрунтованому прийняттю рішень щодо економічного розвитку нашої держави.

Подальші наукові дослідження можуть бути спрямовані на вартісну оцінку економічних збитків унаслідок збройного конфлікту на сході країни та їх взаємозв'язок із обсягом фінансування Збройних Сил України.

\section{Список використаних джерел}

1. Mueller, Hannes The Economic Costs of Conflict. IGC Working Paper. April 2013. $137 \mathrm{p}$.

2. Oxford Handbook of the Economics of Peace and Conflict / Michelle Garfinkel and Stergis Skaperdas eds. NY: Oxford University Press, 2012. - available at : http://www.socsci.uci. edu/ mrgarfin/OUP/papers/Bilmes.pdf.

3. Galvin H. (2003) The Impact of Defence Spending on the Economic Growth of Developing Countries. A Cross-section Study. Defence and Peace Economics. № 14(1). P. 51-59.

4. Department of Defense, Estimated Cost to Each Taxpayer for the Wars in Afghanistan, Iraq and Syria. July 2017. - available at: http://comptroller. defense. gov/ Portals/45/ Documents/defbudget/fy2018/Section_
1090_FY17_NDAA_Cost_of_Wars_to_Per_T axpayer--July_2017.pdf.

5. Ali H. Economic Cost of Conflict in Darfur. Sudan at the Mercy of Killers: Destruction of Villages in Darfur. Working paper, American University in Cairo / Amnesty International. 2011. Report 54/072.

6. Іванов С. В. Вплив збройного конфлікту (війни, бойових дій) на вартість підприємства: монографія. Дн-вськ: Видво Маковецький, 2015. 175 с.

7. Щербіна С. І. Економічні втрати і руйнування України в роки Другої світової війни (на прикладі Черкащини) // Вісник Східноєвропейського університету економіки і менеджменту. Черкаси, 2015. Вип. 2 (19). С. 71-80.

8. Гераймович Г. Вплив війни на економіку 
східних міст України: кейси Маріуполя, Краматорська і Слов'янська. Дослідницький проект Donbas Studies, 2018. URL: https://donbasstudies.org/ author/geraimovych (дата звернення: 17.06.2019).

9. Марко І. Ю., Чернишова І. М. Оцінка збитків національної економіки у період збройного конфлікту на Донбасі. Банківська справа. 2019. Вип. 1 (149). С. 3-12.

10. Про надання щомісячної адресної допомоги внутрішньо переміщеним особам для покриття витрат на проживання, в тому числі на оплату житлово-комунальних послуг: постанова Кабінету Міністрів України від 01 жовтня 2014 р. № 505 // Офіційний вісник України. 2014. № 80. Ст. 2271.

11. Про затвердження Порядку використання коштів, передбачених у державному бюджеті та забезпечення постраждалих учасників Революції Гідності та учасників антитерористичної операції санаторно- курортним лікуванням (зі змінами): постанова Кабінету Міністрів України від 31 березня 2015 р. № 200. // Офіційний вісник України. 2018. № 48. Ст. 247.

12. Про затвердження Порядку використання коштів, передбачених у державному бюджеті для здійснення заходів із соціальної та професійної адаптації учасників антитерористичної операції та постраждалих учасників Революції Гідності (зі змінами): постанова Кабінету Міністрів України від 31 березня 2015 р. № 179. // Офіційний вісник України. 2015. № 30. Ст. 895

13. Про затвердження Порядку організації соціальної та професійної адаптації учасників антитерористичної операції та постраждалих учасників Революції Гідності (зі змінами): постанова Кабінету Міністрів України від 21 червня 2017p. № 432. // Офіційний вісник України. 2018. № 30. Ст. 1369.

\title{
Система показателей оценки ущерба национальной экономики во время вооруженного конфликта
}

\author{
Костантин Харитонов * А \\ *Corresponding author: соискатель, e-mail: aosemenenko@ukr.net \\ А Командование войск связи и кибербезопасности Вооруженных Сил Украины, пр-кт Воздухофлотский 6, г. Киев, 03168, Украина
}

\begin{abstract}
Аннотация
В статье описана система показателей для проведения стоимостной оценки экономических потерь государства, возникающих в результате вооруженного конфликта. Анализ литературы показывает, что сегодня для оценки потерь народного хозяйства во время вооруженного конфликта используются разные методы, каждый из которых имеет свою особую систему показателей. Система показателей, которая даст возможность установить связь между потерями государства во время вооруженного конфликта и экономическим ростом государства, не встречается. Цель работы - поиск системы показателей, которая решит этот проблемный вопрос.

В статье представлены основные составляющие экономических потерь, а именно: прямые военные расходы страны, потерянные доходы, зависящие от численности пострадавшего населения, дополнительные государственные расходы правительства, а также косвенные потери государства, которые возникли с началом вооруженного конфликта: перемещенный капитал, эмиграция квалифицированных рабочих и потеря возможностей получения образования для будущих поколений. Учет всех составляющих экономических потерь, возникающих в результате вооруженного конфликта, влияет не только на общую сумму потерь, но и на уровень экономического развития государства. Применение показателей в предлагаемой системе, с одной стороны, устанавливает связь между
\end{abstract}


экономическим развитием государства и составляющими экономических потерь во время вооруженного конфликта, а, с другой стороны, позволяет проводить оценку этих потерь. Для более обоснованного принятия решений про экономическое развитие нашего государства следует использовать предложенную систему показателей, оценивающих потери народного хозяйства в период вооруженного конфликта. В перспективе, применение такой системы позволит установить связь между расчетными потерями и экономическим ростом государства.

Ключевые слова: вооруженный конфликт, экономический ущерб, валовый внутренний продукт, потеря производительности труда, утраченный заработок.

\title{
System of estimation of losses of the national economy during the of armed conflict
}

\author{
Konstantin Kharitonov *A \\ *Corresponding author: PhD student, e-mail: aosemenenko@ukr.net \\ A Command of the Communications and Cyber Security Forces of the Armed Forces of Ukraine, 6, Povitroflotsky ave., Kyiv, 03168, Ukraine
}

\begin{abstract}
The article describes a system of indicators for carrying out a cost estimation of the economic losses of the state that arise as a result of armed conflict. The analysis of literature shows that today different methods are used to assess the loss to the national economy during an armed conflict, each with its own special system of indicators. A system of indicators that will provide an opportunity to establish a connection between state losses during an armed conflict and economic growth of the state does not take place. The aim of the work is to search for a system of indicators that will solve this problematic issue.

The article presents the main components of economic losses, to be exact: direct military expenditures of the country, lost income, which depends on the number of the affected population, additional government expenditures of the government, as well as indirect losses of the state that arose with the onset of armed conflict: displaced capital, emigration of skilled workers and lost educational opportunities for future generations. Taking into account all the components of economic losses that arise as a result of an armed conflict has an impact not only on the total amount of losses, but also on the level of economic development of the state. The application of indicators in the proposed system, on the one hand, establishes the connection between economic development of the state and the components of economic losses caused by armed conflict, and, on the other hand, make it possible to carry out an estimation of these losses.

For a more reasonable decision-making on the economic development of our state, the proposed system of indicators estimation the loss to the national economy during the period of armed conflict should be used. For the future the application of such a system will allow establishing the connection between calculated losses and economic growth of the state.
\end{abstract}

Keywords: armed conflict, economic losses, gross national product, loss of productivity, lost earnings.

\section{References}

1. Mueller, Hannes The Economic Costs of Conflict. IGC Working Paper. April 2013. $137 \mathrm{p}$.

2. Michelle Garfinkel and Stergis Skaperdas eds., Oxford Handbook of the Economics of Peace and Conflict. New York, Oxford University
Press: Oxford, 2012. available at : http://www.socsci.uci.edu/ mrgarfin/ OUP/ papers/Bilmes.pdf.

3. Galvin H. The Impact of Defence Spending on the Economic Growth of Developing Countries. A Cross-section Study. Defence 
and Peace Economics. 2003. № 14(1). P. 5159.

4. Department of Defense, Estimated Cost to Each Taxpayer for the Wars in Afghanistan, Iraq and Syria. July 2017. available at: http://comptroller. defense. gov/ Portals/45/Documents/defbudget/fy2018/ Section_1090_FY17_NDAA_Cost_of_Wars_t o_Per_Taxpayer--July_2017.pdf.

5. Ali H. Economic Cost of Conflict in Darfur. Sudan at the Mercy of Killers: Destruction of Villages in Darfur // Working paper, American University in Cairo. Amnesty International. 2011. Report 54/072.

6. Ivanov S. V. (2015), "Vplyv zbroinoho konfliktu (viiny, boiovykh dii) na vartist pidpryiemstva: monohrafiia" [Impact of armed conflict (war, fighting) on the cost of the enterprise], Dn-vsk, $175 \mathrm{p}$.

7. Shcherbina, S. I. (2015), "Ekonomichni vtraty $i$ ruinuvannia Ukrainy $v$ roky Druhoi svitovoi viiny (na prykladi Cherkashchyny)" [Economic losses and destruction of Ukraine during the Second World War (on the example of Cherkasy region)], Visnyk Skhidnoiev ropeiskoho universytetu ekonomiky i menedzhmentu. Cherkasy, 2015. № 2 (19). pp. 71-80.

8. Heraimovych H., (2018) "Vplyv viiny na ekonomiku skhidnykh mist Ukrainy: keisy Mariupolia, Kramatorska i Slovianska" [Impact of war on the economy of eastern cities of Ukraine: case of Mariupol, Kramatorsk and Slov'yansk]. available at: https://donbasstudies.org/author/geraimov ych.

9. Marko I. Yu., Chernyshova I. M. Otsinka zbytkiv natsional'noyi ekonomiky u period zbroynoho konfliktu na Donbasi [Estimation of losses of national economy in the period of armed conflict in Donbass] // Bankivs'ka sprava. Kyiv, 2019. № 1 (149). P. 3-12.

10. "Pro nadannia shchomisiachnoi adresnoi dopomohy vnutrishno peremishchenym osobam dlia pokryttia vytrat na prozhyvannia, $v$ tomu chysli na oplatu zhytlovo-komunalnykh posluh" [On providing a monthly targeted assistance to internally displaced persons to cover living expenses, including housing and utilities] : postanova Kabinetu Ministriv Ukrainy № 505. October 01, 2014 // Ofitsiinyi visnyk Ukrainy. 2014. № 80. St. 2271.

11. "Pro zatverdzhennia Poriadku vykorystannia koshtiv, peredbachenykh u derzhavnomu biudzheti ta zabezpechennia postrazhdalykh uchasnykiv Revoliutsii Hidnosti ta uchasnykiv antyterorystychnoi operatsii sanatornokurortnym likuvanniam" [On Approval of the Procedure for Using the Funds Envisaged in the State Budget and Provision of Victims of the Revolution of Dignity and Anti-Terrorist Participants in Sanatorium Treatment]: postanova Kabinetu Ministriv Ukrainy. № 200. March 31, 2015. // Ofitsiinyi visnyk Ukrainy. 2018. № 48. St. 247.

12. "Pro zatverdzhennia Poriadku vykorystannia koshtiv, peredbachenykh u derzhavnomu biudzheti dlia zdiisnennia zakhodiv iz sotsialnoi ta profesiinoi adaptatsii uchasnykiv antyterorystychnoi operatsii ta postrazhdalykh uchasnykiv Revoliutsii Hidnosti" [On Approval of the Procedure for Using the Funds Envisaged in the State Budget for the Implementation of Measures for the Social and Professional Adaptation of the Participants of the Antiterrorist Operation and the Victims of the Victory Revolution Victims]: postanova Kabinetu Ministriv Ukrainy № 179. March 31, 2015. // Ofitsiinyi visnyk Ukrainy. 2015. № 30. St. 895

13. "Pro zatverdzhennia Poriadku orhanizatsii sotsialnoi ta profesiinoi adaptatsii uchasnykiv antyterorystychnoi operatsii ta postrazhdalykh uchasnykiv Revoliutsii Hidnosti" [On Approval of the Order of the Organization of Social and Professional Adaptation of the Participants of the Antiterrorist Operation and the Victims of the Victory Revolution Victims]: postanova Kabinetu Ministriv Ukrainy № 432. June 21, 2017. // Ofitsiinyi visnyk Ukrainy. 2018. № 30. St. 1369. 